\title{
Epigenetic Silencing of DAPK1 Gene is Associated with Faster Disease Progression in India Populations with Chronic Myeloid Leukemia
}

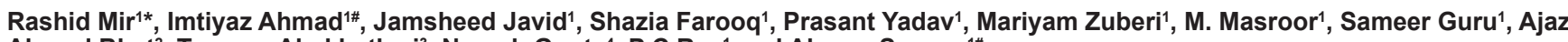
Ahmad Bhat ${ }^{2}$, Tanveer Ah khatlani ${ }^{3}$, Naresh Gupta ${ }^{4}$, P C Ray ${ }^{1}$ and Alpana Saxena ${ }^{1 \#}$

${ }^{1}$ Molecular Oncology Lab, Department of Biochemistry, Maulana Azad Medical College and Associated hospitals, New Delhi, India ${ }^{2}$ Division of Surgical Oncology, Vanderbilt University, Nashville, TN, USA

${ }^{3}$ Department of Medicine, Thrombosis Research, Baylor College of Medicine, Houston TX, USA

${ }^{4}$ Head, Clinical haematology, Department of Medicine, MAMC and Associated Hospitals, India

\#Equal Contribution

\begin{abstract}
Background: One of the major epigenetic changes in human cancer is DNA methylation of tumour suppressor genes which leads to silencing of gene leading to disease progression. Therefore, DNA methylation status of such genes may serve as the epigenetic biomarker for prognosis of human Chronic Myeloid Leukemia.

Material and methods: We used MSP-PCR technique for the analysis of aberrant promoter DAPK1 methylation on $200 \mathrm{CML}$ venous blood samples. Stastical analysis was done for evaluating differences between different parameters using SPSS 16.0 version.

Results: We could detect $91 / 200$ promoter methylation $(45.5 \%)$ in CML patients. Percentage of methylation detected was seen higher in blast phase $(63.07 \%)$ and in accelerated phase $(48.1 \%)$ than in chronic phase $(29.6 \%)$. A significant correlation was seen between CML stages and DAPK1 aberrant methylation. We also found a significant association of DAPK1 methylation in gender and in haematological resistance CML patients. However no correlation was found between DAPK1 promoter methylation and other clinical parameters like age, BCR-ABL type and Thrombocytopenia.

Conclusion: In summary we concluded that methylation status of DAPK1 gene is associated with advanced phase of $\mathrm{CML}$ and may be related to disease progression in chronic myeloid leukemia. Further study on a more number of patients is needed to explore the role of DAPK1 methylation in the prognosis of CML.
\end{abstract}

Keywords: DAPK1 Gene; Chronic myeloid leukemia; MSP-PCR technique; Methylation

\section{Introduction}

Chronic Myelogenous Leukemia (CML) is a malignant cancer of the bone marrow. It causes rapid growth of the blood-forming cells, known as myeloid precursors in the bone marrow, peripheral blood, and body tissues. CML represents about $14 \%$ of all occurrences of leukemia. CML can be divided into three phases, the chronic phase, the accelerated phase and the blast phase. The transition of the disease is not well characterized.

Diagnosis of chronic myeloid leukemia is based on the detection of BCR-ABL gene is a product derived from translocation of chromosome 22 to chromosome 9 . This reciprocal translocation gives rise to BCR$\mathrm{ABL}$ fusion oncogene, results in fusion messenger RNA molecules (e1a2, b2a2, b3a2, and e19a2) of different lengths that are translated into different chimeric protein products (p190, p210 and p230BCR$\mathrm{ABL}$ respectively) that is characterized by constitutive activation of its tyrosine kinase activity. The presence of $B C R / A B L$ rearrangement is the hallmark of CML [1].

The role of aberrant DNA methylation in the development of cancer is well recognized and documented. Addition of the methyl group at the fifth carbon of cytosine of CpGs is the only covalent DNA modification in vertebrate [2]. Gene hypomethylation and gene-specific hypermethylation are the two frequently observed forms of methylation changes which take place in cancer. Global hypomethylation is largely observed in gene poor regions and repetitive DNA and gene-specific hypermethylation of $\mathrm{CpG}$ islands [3].Tumour suppressor gene (TSG) inactivation by promoter region $\mathrm{CpG}$ island hypermethylation occurs in almost all cancer types and is an important mechanism of gene silencing in cancer. To date, there are few reports of hypomethylation of human oncogenes associated with activation by over expression [4]. However, it is well-established that aberrant hypermethylation of the promoter region of tumour suppressor genes is associated with transcriptional silencing and that hypermethylation is an alternative mechanism of functional inactivation [5].

DAPK1 is a $160-\mathrm{kD}$ serine/threonine, microfilament-bound kinase, a candidate tumour suppressor gene which has recently been shown to be involved in gamma interferon-induced apoptosis [6]. In several malignant cell lines, studies have shown that expression of DAPK1 is decreased or absent [7]. Additionally, decreased expression of this gene imparts resistance to interferon-induced apoptosis in cells, and a link between the loss of DAPK1 expression and cellular apoptosis has been shown to facilitate metastasis, at least in one experimental system [8]. Promoter methylation of DAPK1 gene has been observed in multiple tumor types and may increase cellular resistance to programmed cell death [9].

*Corresponding author: Rashid Mir, Molecular Oncology Lab, Department of Biochemistry, Maulana Azad Medical College and Associated Hospitals, New Delhi 110002, India, Tel: +91-9968584601; E-mail: drrashidmamc@gmail.com

Received March 02, 2013; Accepted March 18, 2013; Published March 20, 2013

Citation: Mir R, Ahmad I, Javid J, Farooq S, Yadav P, et al. (2013) Epigenetic Silencing of DAPK1 Gene is Associated with Faster Disease Progression in India Populations with Chronic Myeloid Leukemia. J Cancer Sci Ther 5: 144-149. doi:10.4172/1948-5956.1000201

Copyright: (c) 2013 Mir R. This is an open-access article distributed under the terms of the Creative Commons Attribution License, which permits unrestricted use, distribution, and reproduction in any medium, provided the original author and source are credited. 
Unlike genetic changes in cancer, epigenetic changes are potentially reversible. Epigenetic therapy is a rapidly expanding field and a number of drugs that alter the epigenetic profiles of cancer cells are already in clinical trials. Two hypomethylation agents, 5-azacitidine (Vidaza) and 5-aza-2'-deoxycytidine (Decitabine) are currently in use and are approved therapies for myelodysplastic syndrome $[2,10]$. A significant response to decitabine 5-aza-2_deoxycytidine treatment in chronic myelogenous leukemia and myelodysplastic syndrome has been observed $[11,12]$.

The aim of the current study was to find out aberrant promoter DNA methylation status of DAPK1 gene in chronic myeloid leukemia patients. We used methylation specific PCR (MSP-PCR) for this purpose. The data suggests that its inactivation may play an important role in disease progression of chronic myeloid leukemia.

\section{Material and Methods}

\section{Material and method}

The study was conducted on $200 \mathrm{CML}$ patients collected from Maulana Azad Medical College and Associated Hospitals, New Delhi. Patients were diagnosed clinically by bone marrow hyperplasia, leukocytosis, splenomegaly, high fever and fatigue. The diagnosis was also confirmed by detecting $\mathrm{t}(9 ; 22)$ or BCR/ABL fusion gene (p210 ${ }^{\text {bcr- }}$ ${ }^{\mathrm{abl}}$ ) which is further categorized into b3a2 or b2a2 subtypes on the basis of the BCR breakpoint by Reverse transcription polymerase chain reaction in the molecular oncology lab.

\section{Molecular diagnosis}

\section{Selection criteria of patients:}

- Inclusion Criteria: The study included newly diagnosed CML patients treated with imatinib with a dose of $400 \mathrm{mg}$ to 800 $\mathrm{mg} /$ day. All three stages of cases were included, Chronic phase (CP), Accelerated phase (AP), Blast crisis (BC).

- Exclusion criteria: The exclusion criteria included chronic myelomonocytic leukemia's (CMML) patients, other myeloproliferative disorder patients. The patients follow up was maintained regularly and samples were collected after every six months for imatinib response and mutation studies. The classic criteria used for imatinib mesylate responses in chronic myeloid leukemia for hematologic and molecular responses are depicted in tables $\mathrm{A}$ and $\mathrm{B}$.

\section{Molecular diagnosis of CML by RT-PCR for BCR-ABL:}

- Multiplex RT -PCR: From each CML patient venous blood $(5 \mathrm{ml})$ or $1 \mathrm{ml}$ bone marrow aspirate was collected in EDTA vials. Buffy coat was isolated and washed in red cells lysis buffer. All samples were stored at $-80^{\circ} \mathrm{C}$ until the RNA and genomic DNA was extracted. Total RNA was extracted from about $10^{6}$ white cells by Trizol assay (TRI ${ }^{\mathrm{R}}$ Reagent Sigma CAT\# T9424). The cDNA was synthesized using M-MuLV Reverse Transcriptase and other reaction components (Fermentas CAT\# K1622).The cDNA product was amplified with $1 \mathrm{U} / \mu \mathrm{L}$ Taq polymerase, $240 \mu \mathrm{M} \mathrm{dNTP}, 1.8 \mathrm{M} \mathrm{MgCl}_{2}$, and $0.6 \mu \mathrm{M}$ of the four primers (CA3, C5e, BCR-C, and B2B). Multiplex RT-PCR assay was performed on a PCR machine with the program of $10 \mathrm{sec}$ at $100^{\circ} \mathrm{C}$, one min at $96^{\circ} \mathrm{C}$, three min at $60^{\circ} \mathrm{C}$, two min at $72^{\circ} \mathrm{C}$, $10 \mathrm{sec}$ at $100^{\circ} \mathrm{C}, 20 \mathrm{sec}$ at $97^{\circ} \mathrm{C}, 25 \mathrm{sec}$ at $58^{\circ} \mathrm{C}, 25 \mathrm{sec}$ at $60^{\circ} \mathrm{C}$, $10 \mathrm{sec}$ at $78^{\circ} \mathrm{C}, 50 \mathrm{sec}$ at $73^{\circ} \mathrm{C}$, and 31 times to step five and
$10 \mathrm{~min}$ at $73^{\circ} \mathrm{C}$. The sequence of oligonucleotide primers [13] used in multiplex RT-PCR for BCR-ABL fusion transcripts as the target gene and BCR transcripts as internal control are shown in table 1 . The primer combinations in multiplex RTPCR allowed simultaneous detection of all known types of BCR-ABL and BCR transcripts in one reaction. The expected bands were as follows: $808 \mathrm{bp}$, normal BCR; $481 \mathrm{bp}$, e1a2; 385bp ,b3a2;310bp, b2a2; The quality of RNA and efficiency of cDNA synthesis were analyzed by amplification of BCR gene as an internal control.

- Methyl specific PCR analysis: Genomic DNA was extracted from peripheral blood of CML patients using universal Genomic DNA Extraction Kit (HIMEDIA CAT\# MB504). The quality and integrity of the DNA was determined by the A260/280 ratios. DNA quality was also checked by Ethidium Bromide stained of agarose gel electrophoresis (2\%).

- Bisulphite modification of genomic DNA: Genomic DNA $(1 \mu \mathrm{g})$ was modified with sodium bisulphite using EZ-DNA methylation kit (Zymo research,CAT\# D5001). Bisulphitetreated DNA was used for methylation-specific PCR by using previously published primer sets [14], (Table 2) to distinguish between methylated and unmethylated DNA. The PCR products were electrophoresed on a $2 \%$ agarose gel. After bisulphite processing, all unmethylated cytosine residues were converted to uracil, whereas the methylated cytosine residues remained unchanged. Bisulphite-modified DNA samples were stored at $-80^{\circ} \mathrm{C}$ until use.

- Methyl specific PCR: Modified DNA was PCR amplified with specific primers. Each sample was amplified with two

\begin{tabular}{|c|c|c|c|}
\hline \multicolumn{4}{|c|}{ Table A Hematologic responses } \\
\hline $\begin{array}{l}\text { Complete or major } \\
\text { hematological response }\end{array}$ & \multicolumn{2}{|c|}{$\begin{array}{l}\text { Partial or minor } \\
\text { hematological response }\end{array}$} & $\begin{array}{l}\text { Loos or minimal } \\
\text { hematological response }\end{array}$ \\
\hline $\begin{array}{l}\text { Platelet count }>150 \times 10^{9} / \mathrm{L} \\
\text { WBC count }<10 \times 10^{9} / \mathrm{L} \\
\text { Basophils :<5\% } \\
\text { Differential without } \\
\text { immature granulocytes. } \\
\text { Absence of blasts } \\
\text { and promyelocytes in } \\
\text { peripheral blood } \\
\text { Spleen : nonpalpable } \\
\text { spleen }\end{array}$ & \multicolumn{2}{|c|}{$\begin{array}{l}\text { Platelet count }<450 \times \\
10^{9 / L} \\
\text { WBC count }>10 \times 10^{\%} / \mathrm{L} \\
\text { Basophils : }>10 \%\end{array}$} & $\begin{array}{l}\text { Presence of blasts } \\
\text { and promyelocytes in } \\
\text { peripheral blood } \\
\text { Spleen : Palpable spleen }\end{array}$ \\
\hline \multicolumn{4}{|c|}{ Table B Molecular response } \\
\hline \multicolumn{2}{|c|}{ Major molecular response } & \multicolumn{2}{|c|}{ Minimal or No Molecular response } \\
\hline \multicolumn{2}{|c|}{$\begin{array}{l}\text { It indicates nonquantifiable and } \\
\text { nondetectable bcr-abl gene transcript } \\
\text { (BCR-ABL/ABL) } \leq 0.10^{3} \\
3 \text { log reduction of } B C R-A B L / A B L\end{array}$} & \multicolumn{2}{|c|}{$\begin{array}{l}\text { It indicates quantifiable and detectable } \\
\text { bcr-abl gene transcript (BCR-ABL/ABL) } \\
\geq 0.10^{3} \\
\text { No } 3 \text { log reduction of } B C R-A B L / A B L\end{array}$} \\
\hline C5e & \multicolumn{3}{|c|}{ 5'ATAGGATCCTTTGCAACCGGGTCTGAA3' } \\
\hline B2B & \multicolumn{3}{|c|}{ 5'ACAGAATTCCGCTGACCATCAATAAG3' } \\
\hline BCR-C & \multicolumn{3}{|c|}{ 5' ACCGCATGTTCCGGGACAAAAG3' } \\
\hline CA3 & \multicolumn{3}{|c|}{ 5'TGTTGACTGGCGTGATGTAGTTGCTTGG3' } \\
\hline Transcript & \multicolumn{2}{|c|}{ primers used } & Size (bp) \\
\hline Control BCR & \multicolumn{2}{|c|}{$\mathrm{B} 2 \mathrm{~B}$ and $\mathrm{C} 5 \mathrm{e}$} & $808 \mathrm{bp}$ \\
\hline b2a2 & \multicolumn{2}{|c|}{$\mathrm{B} 2 \mathrm{~B}$ and $\mathrm{CA} 3$} & $310 \mathrm{bp}$ \\
\hline b3a2 & \multicolumn{2}{|c|}{ B2B and $\mathrm{CA} 3$} & $385 b p$ \\
\hline e1a2 & \multicolumn{2}{|c|}{ BCR-C and CA3 } & $481 \mathrm{bp}$ \\
\hline
\end{tabular}

Table 1: Sequence of oligonucleotides used in multiplex RT-PCR for detection of BCR-ABLtranscript as the target gene and BCR transcripts as the internal control. 
sets of primers, one set for methylated DNA and one set for unmethylated DNA.

The PCR amplification process was carried out after optimization of the reaction conditions .PCR products were resolved in agarose gel, and the bands were visualized by Ethidium bromide staining. MS-PCR was performed under the following cycling conditions, predenaturation at $95^{\circ} \mathrm{C}$ for $10 \mathrm{~min}, 45 \mathrm{cycles}$ at $94^{\circ} \mathrm{C}$ for $40 \mathrm{~s}, 60^{\circ} \mathrm{C}$ for $50 \mathrm{~s}$, and $72^{\circ} \mathrm{C}$ for $45 \mathrm{~s}$, followed by final extension at $72^{\circ} \mathrm{C}$ for $10 \mathrm{~min}$.

\section{Statistical analysis}

The data were processed by the SPSS16 Statistical software. Analysis was performed using the SPSS 16.0 software package. The association between DAPK1 and clinicopathological parameters were statically analysed using Chi-square and Fisher exact test. P value of $<0.05$ was considered statistically significant.

\section{Results}

\section{Patient characteristics}

Clinical-pathological features including the age and gender of patients, BCR-ABL type, thrombocytopenia, molecular response haematological response and age group are shown in Table 3 . We could reliably detect both a2b2, a2b3 transcripts in CML patients using multiplex PCR, 29.50\% patients had a2b2 transcript, $62 \%$ patients a $2 \mathrm{~b} 3$ transcript and $8.50 \%$ patients had both transcripts.

\section{Frequency of aberrant DAPK1 methylation in CML}

The expected product size of $103 \mathrm{bp}$ and $98 \mathrm{bp}$ were for unmethylated (U) and methylated (M) DNA of DAPK1 promoter methylation. Only those cases were defined as methylation positive if their sample showed a visual band amplified with Methylated specific primers. PCR products were analyzed on 3.5\% agarose gel and visualized under UV illumination. Representative example is presented in figure 1. Total frequency of aberrant methylation of DAPK1 gene was 91 out of 200 CML patients. The frequencies of aberrant methylation of DAPK1 were different according to the stages of CML.

Association between DAPK1 aberrant methylation and clinicopathological parameters

A correlation between DAPK1 promoter methylation and the clinical characteristics of CML patients is shown in table 4 . No correlation was found between aberrant DAPK1 methylation and age, BCR-ABL type, molecular response and thrombocytopenia.

\section{DAPK1 aberrant methylation in relation to gender}

DAPK1 aberrant methylation was found higher in males than in females. $66(51.5 \%)$ out of 128 males were DAPK1 methylated compared to $25(34.7 \%)$ out of 72 females. Methylation frequencies for DAPK1 showed a significant difference in relation to gender ( $\mathrm{p}$ value 0.02 ). Relation of DAPK1 methylation with respect to gender in three stages of CML is represented in table 5. 28.5\% males and $31.25 \%$ females showed DAPK1 methylation in chronic phase, $57.1 \%$ males

\begin{tabular}{|l|l|l|}
\hline Name & Primer sequence & AT \\
\hline Unmethylated forward primer & GGAGGATAGTTGGATTGAGTTAATGTT & \multirow{6}{*}{$60^{\circ} \mathrm{C}$} \\
\hline Unmethylated Reverse primer & CAAATCCCTCCCAAACACCAA & \\
\hline Methylated forward primer & GGATAGTCGGATCGAGTTAACGTC & \multirow{2}{*}{$60^{\circ} \mathrm{C}$} \\
\hline Methylated Reverse primer & CCCTCCCAAACGCCGA & \\
\hline
\end{tabular}

Table2: Sequence of oligonucleotides used for methylated and unmethylated DNA.

\begin{tabular}{|l|l|l|l|}
\hline Clinicopathological features & & \\
\hline Total number of cases & Males & $\mathbf{2 0 0}$ & $\%$ \\
\hline \multirow{2}{*}{ Gender } & Female & 128 & $64 \%$ \\
\hline \multirow{2}{*}{ Stage } & CP-CML & 81 & $40.50 \%$ \\
\hline \multirow{2}{*}{ BCR-ABL type } & AP-CML & 54 & $27 \%$ \\
\hline & BC-CML & 65 & $32.50 \%$ \\
\hline Therapy & a2b2 & 59 & $29.50 \%$ \\
\hline Age group & a2b3 & 124 & $62 \%$ \\
\hline Molecular response & a2b2/ a2b3 & 17 & $8.50 \%$ \\
\hline Haematological response & Imatinib & 200 & \\
\hline & Age $>45$ & 71 & $35.50 \%$ \\
\hline & Age $<45$ & 129 & $64.50 \%$ \\
\hline & MMR & 50 & $25 \%$ \\
\hline Thrombocytopenia & No MR & 150 & $75 \%$ \\
\hline & MHR & 30 & $15 \%$ \\
\hline & Minor HR & 46 & $23 \%$ \\
\hline & Loss HR & 124 & $62 \%$ \\
\hline & & 100 & $50 \%$ \\
\hline
\end{tabular}

Table 3: Clinical pathological features of CML patients.

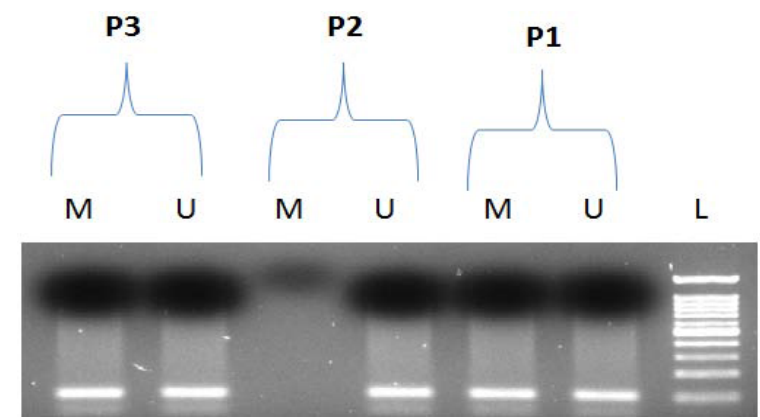

Representative data, U; unmethylation, M; methylation, L; 100bp DNA Ladder.

$\mathrm{P} 1$. Patient 1 is methylated (AP-CML)

P2. Patient 2 is unmethylated (CP-CML).

P3. Patient 3 is methylated (BC-CML).

Figure 1: Example of DAPK1 promoter gene methylation.

and $31.5 \%$ females had aberrant DAPK1 methylation in accelerated phase and in blast phase $51.5 \%$ males and $34.7 \%$ females were showing DAPK1 methylation. A significant correlation was seen in DAPK1 methylation in stages with respect to gender ( $p$ 0.003).

\section{Methylation frequencies during CML progression}

DAPK1 promoter methylation was found higher in advanced stages i.e. blast phase and accelerated phase of CML than in patients in chronic phase. Out of 200 CML patients, 81, 54 and 65 patients were in chronic, accelerated and blast phase respectively. DAPK1 aberrant methylation was detected in 91 patients $(\mathrm{p}>0.0001)$. Forty one $(63 \%)$ patients who showed DAPK1 promoter methylation were in blast phase, $26(48.1 \%)$ in accelerated phase and 24 (29.6\%) patients were in chronic phase. A significant correlation was found between methylation frequencies for DAPK1 and stages of CML $(p>0.0001)$ (Figure 2).

\section{DAPK1 aberrant methylation frequency in haematological} resistant patients

DAPK1 aberrant methylation frequency was found higher in patients showing haematological resistance. Among 200 CML patients, 
30 had major haematological response, 46 minor HR and 124 minimal haematological responses. The aberrant DAPK1 methylation was found as $33.3 \%, 36.9 \%$ and $51.6 \%$ respectively. There was a significant correlation between methylation frequencies for DAPK1 gene with respect to haematological resistance in CML ( $p>0.02)$.

\section{DAPK1 aberrant methylation induced faster disease progression}

Follow-up of patients regarding disease progression in terms of survival was performed with median duration of 60 months.

A total of 91 patients suffered progression with mean follow up time of 5 years. It was observed that the DAPK1 hypermethyaltion cases were significantly associated with faster disease progression $\mathrm{p}<$ 0.004 (Figure 3).

\section{Discussion}

Chronic myeloid leukemia (CML) is a stem cell pluripotent myeloproliferative disorder and consistently associated with the BCRABL1 fusion gene. CML most commonly manifests in chronic phase of the disease those progresses to advanced stage disease (blast crisis) that is resistance to tyrosine kinase inhibitor therapy. Hence it is important to understand biological events involved in CML disease progression. Promoter regions methylation of $\mathrm{CpG}$ islands is observed in various types of tumours. Numerous studies have reported the inactivation of tumour suppressor genes by point mutation or chromosomal deletion in the development of cancers. However epigenetic silencing of tumour suppressor genes by promoter region is also common in human cancers $[15,16]$. As a consequence, hypermethylation can lead to the abolishing transcriptional activity of specific tumour suppressor genes and can play an important role in the induction of the cancer genesis process. It has been claimed by some authors that $65 \%$ of cases of neoplastic diseases may be linked to these epige -netic changes [17]. DAP kinase is involved in the p53-dependent apoptosis pathway and was first identified as a mediator of IFN- $\gamma$-induced apoptosis after IFN$\gamma$-treatment [18-20]. DAPK-1 is frequently silenced in human cancers by methylation and demonstrates tumour and metastasis suppressor properties [21]. The frequency of DAPK1 methylation in different malignancies in the world is depicted in figure 4.

Katzenellenbogen et al. found a correlation between the loss of DAPK1 expression and promoter hypermethylation [22]. A scenario that may explain frequent targeting of the DAPK1 promoter by aberrant DNA methylation is the aberrant recruitment of DNA methyltransferase activity to the DAPK1 promoter by oncogenic proteins [23]. The frequency of DAPK1 methylation was found to be $28.1 \%$ in urothelial carcinoma in Korean population by Hee Jung et.al. [24]. Gonzalez et al. showed 14\% DAPK1 aberrant methylation in neuroblastic tumours [25]. Kim et al. detected $60.9 \%$ promoter DAPK1 methylation in B-cell lymphoma in Korean population [26]. A study by Ekmek et al. observed the frequency of DAPK1 methylation in pediateric AML and adult AML by $70 \%$ and $55 \%$ respectively [27]. $67 \%$ methylation was detected in multiple myeloma by Margeret H.L et al. [28] Also 23.20\% promoter DAPK1 methylation was detected in childhood acute lymphoblastic leukemia [29]. In South Korean population DAPK1 promoter had $94.3 \%$ methylation in Ocular adnexal lymphoma [30]. 62.7\% DAPK1 methylation was shown by J Qian et al. in MDS patients [31] where as it was $23.8 \%$ in Head and Neck cancer [32]. In different haematological malignancies aberrant 28\% DAPK1 methylation was reported [33]. In CML blast crisis 6\%

\begin{tabular}{|c|c|c|c|c|c|c|}
\hline Clinical feature & No. & $\begin{array}{l}\text { DAPK1 } \\
\text { unmethylated }\end{array}$ & $\%$ & $\begin{array}{l}\text { DAPK1 } \\
\text { Methylated }\end{array}$ & $\%$ & $P$ value \\
\hline Patients & 200 & 109 & 54.5 & 91 & $45.5 \%$ & $<0.0001$ \\
\hline Males & 128 & 62 & $48.4 \%$ & 66 & $51.5 \%$ & \multirow[b]{2}{*}{0.02} \\
\hline Female & 72 & 47 & $65.2 \%$ & 25 & $34.7 \%$ & \\
\hline CP-CML & 81 & 57 & $70.3 \%$ & 24 & $29.6 \%$ & \multirow{3}{*}{$<0.0001$} \\
\hline AP-CML & 54 & 28 & $51.8 \%$ & 26 & $48.1 \%$ & \\
\hline BC-CML & 65 & 24 & $36.9 \%$ & 41 & $63.07 \%$ & \\
\hline $\mathrm{A} 2 \mathrm{~b} 2$ & 59 & 35 & $59.3 \%$ & 24 & $40.6 \%$ & \multirow{3}{*}{0.5} \\
\hline A2B3 & 124 & 64 & $51.6 \%$ & 60 & $48.3 \%$ & \\
\hline $\mathrm{A} 2 \mathrm{~b} 2 / \mathrm{A} 2 \mathrm{~b} 3$ & 17 & 10 & $58.8 \%$ & 7 & $41.1 \%$ & \\
\hline Imatinib & 200 & 109 & $54.5 \%$ & 91 & $45.5 \%$ & \\
\hline Age $>45$ & 71 & 39 & $54.9 \%$ & 32 & $45.07 \%$ & \multirow{2}{*}{0.9} \\
\hline Age $<45$ & 129 & 70 & $54.2 \%$ & 59 & $45.7 \%$ & \\
\hline MMR & 50 & 31 & $62 \%$ & 19 & $38 \%$ & \multirow[b]{2}{*}{0.4} \\
\hline No MR & 150 & 78 & $52 \%$ & 72 & $48 \%$ & \\
\hline MHR & 30 & 20 & $66.6 \%$ & 10 & $33.3 \%$ & \multirow{3}{*}{0.02} \\
\hline Minor HR & 46 & 29 & 63.04 & 17 & $36.9 \%$ & \\
\hline Loss HR & 124 & 60 & $48.3 \%$ & 64 & $51.6 \%$ & \\
\hline Thrombocytopenia & 100 & 52 & 52 & 48 & $48 \%$ & 0.5 \\
\hline
\end{tabular}

Table 4: Association of DAPK1 aberrant methylation with clinicopathological parameters.

\begin{tabular}{|l|l|l|l|l|l|l|l|}
\hline Stage & $\begin{array}{l}\text { No. of } \\
\text { patients }\end{array}$ & No. of Males & $\begin{array}{l}\text { DAPK1 } \\
\text { methylation }\end{array}$ & $\begin{array}{l}\text { No } \\
\text { methyltion }\end{array}$ & $\begin{array}{l}\text { No. of } \\
\text { females }\end{array}$ & DAPK1 methylation \\
\hline Chronic phase & 81 & 49 & $14(28.5 \%)$ & $35(71.5 \%)$ & 32 & $10(31.25 \%)$ \\
\hline $\begin{array}{l}\text { Accelerated } \\
\text { phase }\end{array}$ & 54 & 35 & $20(57.1 \%)$ & $15(42.9 \%)$ & 19 & $6(31.5 \%)$ \\
\hline Blast phase & 65 & 44 & $32(72.7 \%)$ & $12(27.3 \%)$ & 21 & $9(42.8 \%)$ \\
\hline Total & 200 & 128 & $66(51.5 \%)$ & $62(48.5 \%)$ & 72 & $25(34.7 \%)$ \\
\hline
\end{tabular}

Table 5: DAPK1 methylation with respect to gender in stages of CML. 
DAPK1 methylation was reported [34] and by Qian J etal showed 51\% DAPK1 aberrant methylation in chronic myeloid leukemia patients [35]. Seog et al showed DAPK1 methylation profiles in major types of human cancers as $70 \%$ in cervix carcinoma, $71 \%$ in stomach cancer, $57 \%$ in colon cancer, $13 \%$ in liver cancer, $87 \%$ in larynx carcinoma, $26 \%$ in breast carcinoma and 70\% in lung cancer [36]. Review of DAPK1 methylation in different malignancies is shown in table 6.

We investigated the methylation status of the DAPK1 gene in CML chronic phase, CML accelerated phase and CML blast crisis samples. We could not find any correlation between DAPK1 methylation and various clinic pathologic factors including age, chromosomal abnormality, thrombocytopenia and BCR-ABL type.

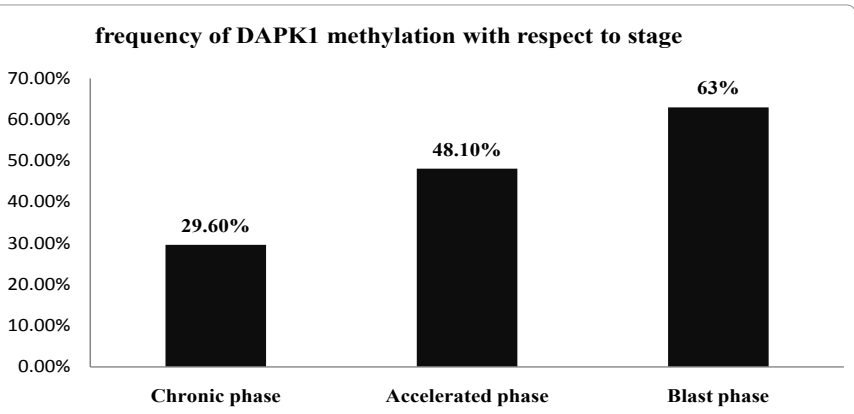

Figure 2: Frequency of DAPK1 methylation in CML patients with respect to stage.

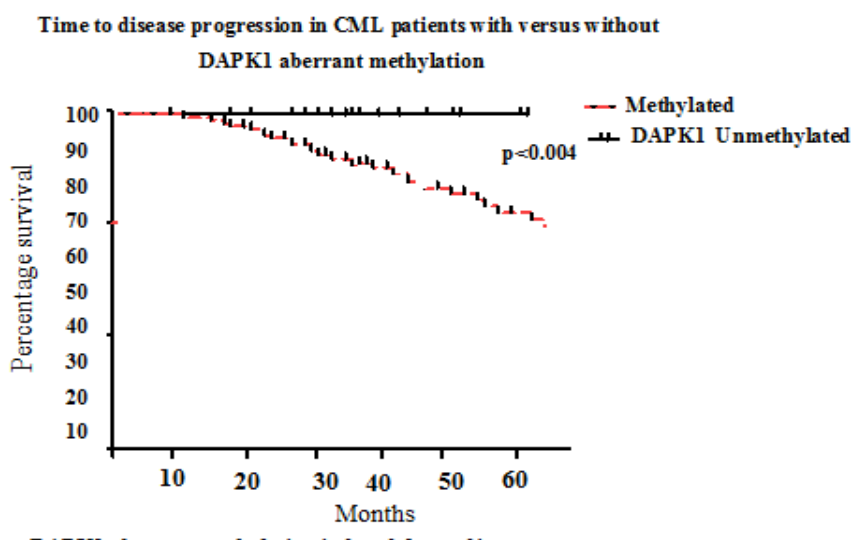

DAPKl aberrant methylation induced faster disease progression

Figure 3: DAPK1 aberrant methylation induced faster disease progression.

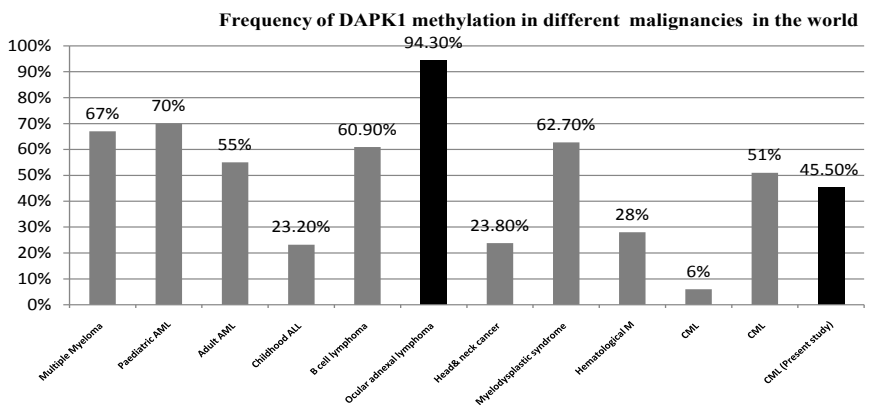

Figure 4: DAPK1 methylation in different malignancies in the world

\begin{tabular}{|l|l|l|}
\hline Cancer type & Author & $\%$ methylation. \\
\hline Multiple Myeloma (26) & Margaret et al. & $67 \%$ \\
\hline Paediatric AML (25) & Ekmekd et al. & $70 \%$ \\
\hline Adult AML (25) & Ekmekd et al. & $55 \%$ \\
\hline Childhood ALL (27) & Gutierrez et al. & $23.2 \%$ \\
\hline B cell lymphoma (24) & Sung Kim et al. & $60.9 \%$ \\
\hline Ocular adnexal lymphoma (28) & Ho-Kyung et al. & $94.3 \%$ \\
\hline Head and neck cancer (30) & Masayuki et al. & $23.8 \%$ \\
\hline Myelodysplastic syndrome (29) & Qian et al. & $62.7 \%$ \\
\hline Hematological malignancies. (31) & Tamer et al. & $28 \%$ \\
\hline CML (32) & Eisuke et al. & $6 \%$ \\
\hline CML (33) & Qian et al. & $51 \%$ \\
\hline Our study & & $45.5 \%$ \\
\hline
\end{tabular}

Table 6: Review of DAPK1 methylation in different malignancies.

In this study, our results indicate that DAPK1 methylation is associated with the progression of CML. Among total 91 (45.5\%) DAPK1 methylation positive patients, percentage of methylation was found higher in blast phase, accelerated phase than in chronic phase with a significant correlation $(p>0.0001)$. We also observed a significant correlation between methylation frequencies for DAPK1 gene with respect to haematological resistance in CML ( $p>0.02)$. The frequency of methylation was higher in patients showing minor or minimal haematological response than in patients showing major haematological resistance. Our results showed a significant association of gender with DAPK1 promoter methylation in CML patients $(\mathrm{P}<$ $0.02)$, Males were showing disease progression more than females in relation to DAPK1 methylation. We observed a significant correlation of DAPK1 methylation in three stages of CML with respect to gender $(\mathrm{P}<0.003)$. Hence the assessment of the changes in DAPK1 methylation can be a prognostic factor for CML.Thus, DAPK1 gene hypermethylation might be a valuable marker for evaluation of treatment outcome in chronic myeloid leukemia.

\section{Conclusion}

The data suggests that disease progression in CML might be closely associated with DAPK1 promoter methylation. Hence, detecting DAPK1 epigenetic changes in DNA may be a promising target for molecular analysis in chronic myeloid leukemia. However, further study will be needed to determine the role of DAPK1 methylation in the prognosis of CML.

\section{References}

1. Chasseriau J, Rivet J, Bilan F, Chomel JC, Guilhot F, et al. (2004) Characterization of the different BCR-ABL transcripts with a single multiplex RT-PCR. J Mol Diagn 6: 343-347.

2. Esteller M (2008) Epigenetics in cancer. N Engl J Med 358: 1148-1159.

3. Galm O, Herman JG, Baylin SB (2006) The fundamental role of epigenetics in hematopoietic malignancies. Blood Rev 20: 1-13.

4. Jones PA, Baylin SB (2002) The fundamental role of epigenetic events in cancer. Nat Rev Genet 3: 415-428.

5. Chim CS, Wong KY, Loong F, Srivastava G (2004) SOCS1 and SHP1 hypermethylation in mantle cell lymphoma and follicular lymphoma: implications for epigenetic activation of the Jak/STAT pathway. Leukemia 18: 356-358.

6. Esteller M, Gaidano G, Goodman SN, Zagonel V, Capello D, et al. (2002) Hypermethylation of the DNA repair gene O(6)-methylguanine DNA methyltransferase and survival of patients with diffuse large B-cell lymphoma. 
Citation: Mir R, Ahmad I, Javid J, Farooq S, Yadav P, et al. (2013) Epigenetic Silencing of DAPK1 Gene is Associated with Faster Disease Progression in India Populations with Chronic Myeloid Leukemia. J Cancer Sci Ther 5: 144-149. doi:10.4172/1948-5956.1000201

J Natl Cancer Inst 94: 26-32.

7. Inbal B, Cohen O, Polak-Charcon S, Kopolovic J, Vadai E, et al. (1997) DAP kinase links the control of apoptosis to metastasis. Nature 390: 180-184.

8. Rosas SL, Koch W, da Costa Carvalho MG, Wu L, Califano J, et al. (2001) Promoter hypermethylation patterns of p16, O6-methylguanine-DNAmethyltransferase, and death-associated protein kinase in tumors and saliva of head and neck cancer patients. Cancer Res 61: 939-942.

9. Tang X, Khuri FR, Lee JJ, Kemp BL, Liu D, et al. (2000) Hypermethylation of the death-associated protein (DAP) kinase promoter and aggressiveness in stage I non-small-cell lung cancer. J Natl Cancer Inst 92: 1511-1516.

10. Dunn BK (2003) Hypomethylation: one side of a larger picture. Ann N Y Acad Sci 983: 28-42.

11. Kantarjian HM, O'Brien S, Cortes J, Giles FJ, Faderl S, et al. (2003) Results of decitabine (5-aza-2'deoxycytidine) therapy in 130 patients with chronic myelogenous leukemia. Cancer 98: 522-528

12. Daskalakis M, Nguyen TT, Nguyen C, Guldberg P, Köhler G, et al. (2002) Demethylation of a hypermethylated P15/INK4B gene in patients with myelodysplastic syndrome by 5-Aza-2'-deoxycytidine (decitabine) treatment. Blood 100: 2957-2964

13. Rosline H, Majdan R, Wan Zaidah A, Rapiaah M, Selamah, et al. (2008) One step multiplex RT-PCR for BCR-ABL gene in Malaysian patients diagnosed as leukaemia. Malaysian Journal of Medical Sciences 12: 153

14. Galm O, Wilop S, Reichelt J, Jost E, Gehbauer G, et al. (2004) DNA methylation changes in multiple myeloma. Leukemia 18: 1687-1692.

15. Baylin SB, Herman JG, Graff JR, Vertino PM, Issa JP (1998) Alterations in DNA methylation: a fundamental aspect of neoplasia. Adv Cancer Res 72: 141-196.

16. Robertson KD (2001) DNA methylation, methyltransferases, and cancer. Oncogene 20: 3139-3155.

17. Esteller M, Sanchez-Cespedes M, Rosell R, Sidransky D, Baylin SB, et al. (1999) Detection of aberrant promoter hypermethylation of tumor suppressor genes in serum DNA from non-small cell lung cancer patients. Cancer Res 59: $67-70$.

18. Raveh T, Droguett G, Horwitz MS, DePinho RA, Kimchi A (2001) DAP kinase activates a p19ARF/p53-mediated apoptotic checkpoint to suppress oncogenic transformation. Nat Cell Biol 3: 1-7.

19. Feinstein E, Druck T, Kastury K, Berissi H, Goodart SA, et al. (1995) Assignment of DAP1 and DAPK--genes that positively mediate programmed cell death triggered by IFN-gamma--to chromosome regions $5 \mathrm{p} 12.2$ and 9q34.1, respectively. Genomics 29: 305-307.

20. Deiss LP, Feinstein E, Berissi H, Cohen O, Kimchi A (1995) Identification of a novel serine/threonine kinase and a novel $15-\mathrm{kD}$ protein as potential mediators of the gamma interferon-induced cell death. Genes Dev 9: 15-30.

21. Gozuacik D, Kimchi A (2006) DAPk protein family and cancer. Autophagy 2 74-79.

22. Hoque MO, Begum S, Topaloglu O, Jeronimo C, Mambo E, et al. (2004) Quantitative detection of promoter hypermethylation of multiple genes in the tumor, urine, and serum DNA of patients with renal cancer. Cancer Res 64: 5511-5517.

23. Brenner C, Deplus R, Didelot C, Loriot A, Viré E, et al. (2005) Myc represses transcription through recruitment of DNA methyltransferase corepressor. EMBO J 24: 336-346.

24. Hee JP, Eui JL, Sang YH, Ghee YK, Young LO, et al. (2010) Prognostic significance of methylation profiles in urothelial carcinomas of bladder. KoreanJPathol 44: 623-630.

25. Gonzalez-Gomez P, Bello MJ, Lomas J, Arjona D, Alonso ME, et al. (2003) Aberrant methylation of multiple genes in neuroblastic tumours. relationship with MYCN amplification and allelic status at 1p. Eur J Cancer 39: 1478-1485.

26. Sung SK, Young HC, Chang WH, Yoo DC, Youngkyu P, et al. (2009) DNA Methylation Profiles of MGMT, DAPK1, hMLH1, CDH1, SHP1, and HIC1 in B-Cell Lymphomas. KoreanJPathol 43: 420-7.

27. Ekmekci CG, Gutiérrez MI, Siraj AK, Ozbek U, Bhatia K (2004) Aberrant methylation of multiple tumor suppressor genes in acute myeloid leukemia. Am J Hematol 77: 233-240.

28. Ng MH, To KW, Lo KW, Chan S, Tsang KS, et al. (2001) Frequent deathassociated protein kinase promoter hypermethylation in multiple myeloma. Clin Cancer Res 7: 1724-1729.

29. Gutierrez MI, Siraj AK, Bhargava M, Ozbek U, Banavali S, et al. (2003) Concurred methylation of multiple genes in childhood ALL. Leukemia 17: 1485 1850

30. Choung HK, Kim YA, Lee MJ, Kim N, Khwarg SI (2012) Multigene methylation analysis of ocular adnexal MALT lymphoma and their relationship to Chlamydophila psittaci infection and clinical characteristics in South Korea. Invest Ophthalmol Vis Sci 53: 1928-1935.

31. Qian J, Yao DM, Lin J, Wang YL, Han LX, et al. (2010) Methylation of DAPK promoter: frequent but not an adverse prognostic factor in myelodysplastic syndrome. Int J Lab Hematol 32: 74-81.

32. Hasegawa M, Nelson HH, Peters E, Ringstrom E, Posner M, et al. (2002) Patterns of gene promoter methylation in squamous cell cancer of the head and neck. Oncogene 21: 4231-4236.

33. Fandy TE, Herman JG, Kerns P, Jiemjit A, Sugar EA, et al. (2009) Early epigenetic changes and DNA damage do not predict clinical response in an overlapping schedule of 5-azacytidine and entinostat in patients with myeloid malignancies. Blood 114: 2764-2773.

34. Uehara E, Takeuchi S, Yang Y, Fukumoto T, Matsuhashi Y, et al. (2012) Aberrant methylation in promoter-associated $\mathrm{CpG}$ islands of multiple genes in chronic myelogenous leukemia blast crisis. Oncol Lett 3: 190-192.

35. Qian J, Wang YL, Lin J, Yao DM, Xu WR, et al. (2009) Aberrant methylation of the death-associated protein kinase 1 (DAPK1) CpG island in chronic myeloid leukemia. Eur J Haematol 82: 119-123.

36. Park SY, Kim BH, Kim JH, Cho NY, Choi M, et al. (2007) Methylation profiles of $\mathrm{CpG}$ island loci in major types of human cancers. J Korean Med Sci 22 311-317. 